\title{
OKIEM ODBIORCY: OBRAZY NAOCZNE I WYOBRAŻONE. ALBUM ECHOES SHADES PIOTRA ZBIERSKIEGO
}

ANNA MARIA ZaRYCHTA

Wydział Operatorski i Realizacji Telewizyjnej PWSFTviT w Łodzi Direction of Photography and Television Production Department, The Polish National Film Television and Theatre School in Łódź a.zarychta@filmschool.lodz.pl ORCID: 0000-0002-4892-1613

Wyobraźnia znajduje więcej rzeczywistości w tym, co się ukrywa, niż $w$ tym, co jest widoczne. G. Bachelard

W poniższym tekście, do którego napisania impulsem stał się właśnie wydany album Piotra Zbierskiego Echoes Shades (Cienie echa, 2020), widzenie (oglądanie albumu) jest potraktowane zarówno jako zadanie zanurzone w refleksji naukowej (tj. wybranych jej obszarach), jak i - odwołując się do Carla Gustava Junga - jako doznawanie (także tego, co wymyka się racjonalności) oraz czucie, które stwarzają świadomość, „skąd coś pochodzi, dokąd może zmierzać i co może czynić”, i co za pośrednictwem intuicji pozwala „zerkać za węgieł”. Istotna jest próba uchwycenia migotliwej w swoim charakterze gry relacyjnej, w jaką wciąga nas obraz z fotografii, pobudzając naszą wyobraźnię, nasz system skojarzeń i intuicji. W szczególności w przypadku, gdy obrazy sugerują coś jeszcze, swego rodzaju hierofanię tu w rozumieniu przelotnego poczucia obecności metafizyki (czy może raczej potrzeby jej obecności) w codziennym życiu. $Z$ jej ujawnianiem się jedynie w „mgnieniu oka” czy - jakby powiedział Eliade (Traktat o historii

1 C.G. Jung, Życie symboliczne, tłum. R. Reszke, Warszawa 2007, s. 58-60 (rozdział Podstawy psychologii analitycznej). 
religii) ${ }^{2}$ - jako u chw ycen ie poprzedzające refleksję, poprzez które ujawnia się metafizyczna warstwa obrazu.

Piotr Zbierski - uznany za jednego z najciekawszych polskich fotografów młodego pokolenia - właśnie wydał swój drugi album Echoes Shades ${ }^{3}$. Jego pierwsza publikacja, Push the Sky Away (2016), znalazła się wśród finalistów nagrody Arles Author Book Award (2017) i zawierała m.in. cykl fotografii Pass by Me, nagrodzony w konkursie Leica Oskar Barnack Award Newcomer (2012). Obie publikacje to jednocześnie subiektywny zapis duchowego świata autora, jak i sugestywny zbiór fotografii dokumentujących kilkanaście podróży po Europie, Azji i Afryce, które to fotografie w pewnym sensie wpisują się w antropologiczny dyskurs - zarówno w ujęciu przywoływanej przez Krzysztofa Olechnickiego Elizabeth Edwards, która w artykule Beyond the Boundary: A Consideration of the Expressive in Photography and Antropology (1997) postuluje nowe spojrzenie na antropologiczny dokument $^{4}$, jak i w bardziej ogólnej refleksji, gdzie ważnym aspektem konstytuującym antropologiczną wizualność jest po prostu idea „patrzenia

2 W prezentowanym tekście pojawi się wiele odwołań do prac Junga i Eliadego, niezależnie od kontrowersji towarzyszących ich refleksji nad metafizyczną i symboliczną wspólnotą kultur archaicznych czy próbą ukazania pozahistorycznego obrazu świata. W obu przypadkach potrzeba poznania pewnych ponadczasowych i uniwersalnych struktur obrazujących naturę ludzką jest bliska wizualnym poszukiwaniom Piotra Zbierskiego, którego fotografie są tu przedmiotem analizy. Towarzysząca ich, tj. Junga i Eliadego, refleksji metodologiczna niejednoznaczność, łatwość dygresji i autorefleksji, jeszcze w innym, także formalnym wymiarze pasuje do specyfiki albumu Echoes Shades.

3 Prace zebrane $\mathrm{w}$ albumie prezentowano m.in. $\mathrm{w}$ ramach łódzkiego Międzynarodowego Festiwalu Fotografii w 2019 roku, jak i wcześniej, w trakcie FotoFever Paris w Carrousel du Louvre (2018). Kuratorką wystawy na łódzkim fotofestiwalu była Peggy Sue Amison (USA/IRE), dyrektor artystyczna East Wing, platformy poświęconej fotografii założonej w 2012 roku w katarskim mieście Doha; http://fotofestiwal.com/2019/wystawy/piotr-zbierski-cienie-echa/ [dostęp 3.02.2020].

${ }^{4} \mathrm{~K}$. Olechnicki, Wartość estetyczna a poznanie naukowe $w$ socjologii i antropologii obrazu, [w:] Co widać?, red. J. Kaczmarek, M. Krajewski, Poznań, s. 37. 
na innych ludzi"5. Olechnicki, przywołując m.in. Edwards, wskazuje na problem "granicy" między wiedzą naukową i nienaukową w badaniach nad sztuką, gdzie posługiwanie się wizualnymi metodami badawczymi bywa w mniejszym lub większym stopniu wejściem na „epistemologiczną skórkę od banana, którą jest problem sztuki, wartości estetycznych rozpatrywanych na rozmaitych poziomach relacji pomiędzy sztuką a nauką"6. Oczywiście wejście na grunt przestrzeni dyskursywnych powiązanych $\mathrm{z}$ antropologią rodzi szereg niebezpieczeństw (ale, co istotne, jest tu jedynie impulsem do refleksji), lecz równocześnie pozwala na postawienie pytań wskazujących na możliwe konteksty odbiorcze towarzyszące recepcji fotografii Piotra Zbierskiego.

Zebrane w obu albumach wizualne eseje Zbierskiego są nieustającym samopoznaniem (co autor bardzo wyraźnie podkreśla w wywiadach), ale i metafizycznym poszukiwaniem wspólnego nam kulturowego kodu człowieczeństwa - swoistą próbą odpowiedzi na postawione sobie pytanie o potrzebę kontaktu z tym, co transcendentne, o uchwycenie swoistej wspólnoty myślenia magicznego. Potrzebą, która wyraźnie pojawiła się w fotografiach zebranych w trzeciej część albumu Push the Sky Away i której kontynuację stanowi obecny projekt: Cienie echa. Zbierski, podobnie jak wielu innych artystów, posługując się medium fotografii, wybiera konwencję dokumentalną, która - jak pisze Marianna Michałowska - z jednej strony pozostaje świadoma przypisanego jej zadania obiektywizacji obrazu przeszłości, a z drugiej - wypracowała własny dyskurs krytyczny wobec tej obiektywizacji ${ }^{7}$. Fotografie stają się w takim ujęciu czymś na kształt „antropologicznych miniatur”, których sens wyrasta z napięcia między realnym a wyobrażonym, między rzeczywistością a ekspresją. Zarówno istnieją, jak i dają się odczytywać w różnych płaszczyznach znaczeniowych.

5 J. Dziewit, A. Pisarek, Ciemnia antropologiczna, [w:] Patrzenie i widzenie w kontekstach kulturoznawczych, red. J. Dziewit, M. Kołodziej, A. Pisarek, Katowice 2016, s. 11.

${ }^{6}$ K. Olechnicki, op. cit., s. 32.

7 M. Michałowska, Foto-teksty w badaniach historiograficznych - wokół refleksji Paula Ricoeura, „Dyskurs” 2011, nr 12, s. 287; https://www.asp.wroc.pl/?module $=$ StaticContent $\&$ controller $=$ Main\&id=759\&__seoName=Dyskurs+12 [dostęp 15.03.2020]. 
Pisząc o foto-tekstach, Michałowska - idąc śladem Martina Jaya - przywołuje Kantowskie rozróżnienia pomiędzy Erlebis i Ehrfahrung. Erlebnis, jako przeżycie lub doświadczenie przeżywane, odpowiadałoby „zdarzeniu”, które znajduje swój wyraz w „zapisie zdarzenia” - w fotografii/fotografiach czy w stworzonych z ich układu narracjach. Odpowiednik Ehrfahrung to doświadczenie refleksyjne, związane z pracą pamięci ${ }^{8}$. Autorka pisze dalej:

do wyrażenia obu wymiarów konieczna jest narracja, tak autora, jak i odbiorców, nie tylko by doświadczyć ich „odczytania” (inaczej, poddać interpretacji), lecz również by wyrazić przeżywane za ich sprawą zdarzenie 9 .

W przypadku obu projektów Zbierskiego nie mamy typowej dla foto-tekstów pisanej narracji autora. Pozostajemy sam na sam z wizualnością, niemal pozbawioną słownego kontekstu, sprowadzonego jedynie do krótkiego wstępu. Doświadczenie refleksyjne staje się pracą naszych rozpoznań i pamięci. Swoista ucieczka autora przed stylistycznym sprostaniem ubrania w słowa widzialnej rzeczywistości - daje nam wolność.

Echoes Shades ${ }^{10}$ - stanowiące przedmiot analizy - to, jak nas informuje wstęp, opowieść o relacjach sił Natury i Kultury, przede wszystkim o wpisanym weń człowieku. Narracja zarówno w albumie, jak i na wystawach tworzy własne rozwidlone i krzyżujące się ścieżki, za każdym razem inne (il. 1). Wybierając i układając fotografie, Zbierski tworzy swoją opowieść o tym, co metafizyczne, pierwotne i wspólne w przypadkowo uchwyconych widokach otaczającego go świata (jak w refleksji Mircei Eliadego: to, co metafizyczne, ujawnia się jedynie w „mgnieniu oka”ll). Pozbawiona chronologiczności, swoistej jedności miejsca czy też innego klasycznie porządkującego sensu,

8 Ibidem, s. 288.

9 Ibidem.

10 Ilustracje zamieszczono dzięki uprzejmości Piotra Zbierskiego; wszystkie pochodzą m.in. z jego dokumentacji albumu i wystawy, która odbyła się w ramach Międzynarodowego Festiwalu Fotografii w Łodzi (2019).

${ }^{11}$ W rozważaniach Eliadego dla zrozumienia symboli otaczającego nas świata istotne jest - przywołane tu we wstępie - poprzedzające refleksję „uchwycenie”, poprzez które ujawnia się metafizyczna warstwa obrazu. Eliade kontynuuje tę myśl w Obrazach i symbolach: mityczne obrazy powstają w "mgnieniu oka” i przez „mgnienie oka” są postrzegane; M. Eliade, Traktat o historii religii, tłum. 
opowieść otwiera się na możliwe odczytania. Niczym proces historiograficzny Ricoeura: nie jest ciągiem następujących po sobie czynności, lecz jawi się jako nakładające się na siebie poziomy, z których każdy jest nieustanną interpretacją, wyborem obrazów, trybów wyjaśniania i reprezentacji ${ }^{12}$. Historia, jak zauważa francuski hermeneuta, także działa po trosze jak przyrząd optyczny: przybliża i oddala poszczególne obrazy w przestrzeni i w czasie, tworzy mikro- i makrohistorie. Dodatkowo w przypadku prezentowanych przez Zbierskiego wystaw, albumów czy realizacji multimedialnych (łączących np. fotografie i utrzymany $\mathrm{w}$ podobnej stylizacji materiał fil-
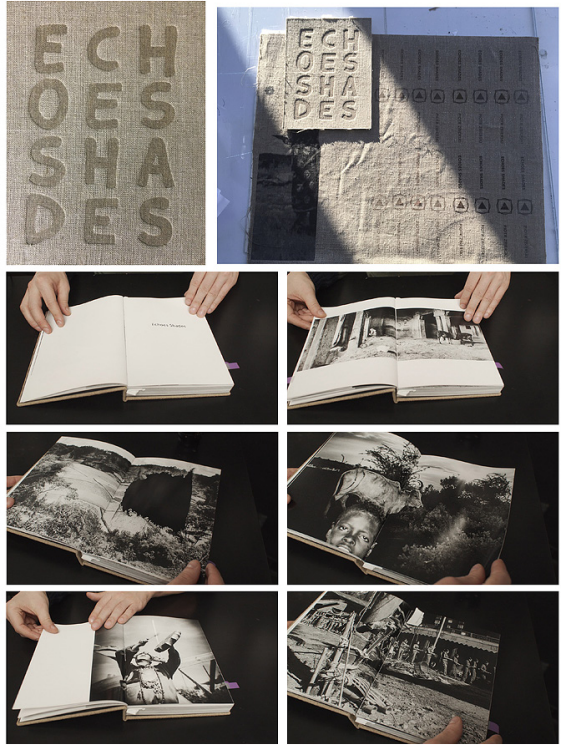

Il. 1. Prezentacja albumu Piotra Zbierskiego Echoes Shades (2020) mowy ${ }^{13}$ ) układ prac to swoiste écriture automatique, które - przywołując kolejny raz Eliadego - jako myślenie symboliczne dopuszcza do głosu „nieświadomość”, stając się jednocześnie „oknem” świata pozahistorycznego ${ }^{14}$. Jak pisze dalej filozof: „umysł, aby dotrzeć do ostatecznej rzeczywistości świata, posługuje się obrazami, to właśnie dlatego, że rzeczywistość ta przejawia się w sposób pełen sprzeczności, a zatem nie jest możliwe wyrażenie jej w języku dyskursywnym"15.

J. Wierusz-Kowalski, Łódź 1993, s. 212; idem, Obrazy i symbole. Szkice o symbolizmie magiczno-religijnym, tłum. M. i P. Rodakowie, Warszawa 1998, s. 66.

12 P. Ricoeur, Historia, pamięć, zapomnienie, cyt. za: M. Michałowska, op. cit., s. 257.

13 Slideshow łączący fotografie i filmy, por. https://vimeo.com/350656912 [dostęp 2.03.2020].

${ }_{14}$ M. Eliade, Obrazy i symbole..., op. cit., s. 16 i 204.

15 Ibidem, s. 18. 
Na fotografiach w Echoes Shades - które wyrosły z oporu wobec absurdu i bezsensu życia zanurzonego we współczesnej nachalnej faktyczności ${ }^{16}$ odnajdziemy obraz kultur animistycznych, w szerokim rozumieniu tego pojęcia. Jest tu zarówno pragnienie powrotu do pierwotnej wiary, zanurzenie w naturalnej obecności pierwiastka duchowego właściwego każdej cząsteczce wszechświata, gdzie wszystko posiada swojego ducha i świadomość, jak i obrazy synkretyzmu różnych form wierzeń animistycznych z tradycyjnymi systemami religijnymi (il. 2-3). Przykładem są fotografie z Indonezji, gdzie animizm współistnieje z szamanizmem, hinduizmem, buddyzmem, chrześcijaństwem oraz islamem; wspólnota plemienna zamieszkująca rejon Tana Toraja w swoich pogrzebowych rytuałach przejścia łączy z powodzeniem manizm i chrześcijaństwo, w pewnym sensie przywracając na chwilę zmarłych członków rodziny żywej wspólnocie (podobnie jak w ceremonii tzw. obracania zmarłych na Madagaskarze). Niejednoznaczne obrazy indonezyjskich ceremonii pogrzebowych i kultu przodków spotykają się z obrzędami syberyjskich szamanów, które łączą się z „zamawianiem” podlaskich szeptuch (w jednym i drugim przypadku konieczna jest łączność z duchami). Fotografie z afrykańskiej doliny Omo sąsiadują z tymi wykonanymi w Indiach czy Rumunii. Ludzie przyozdobieni rogami, kije, krowy i krowie dzwonki, drzewa, dzieci, krajobrazy (pustkowia) - tworzą kolejną wizualną, ale i duchową wspólnotę. Nie są to widoki typowe, chociażby te z tak atrakcyjnej wizualnie afrykańskiej doliny rzeki Omo, której mieszkańcy zarabiają, pozując turystom do fotografii. Mrok, prześwietlenia, ucięte kadry, dziwne ujęcia nie opowiadają prostej antropologicznej historii o niezwykłych wyglądach i plemiennych obrzędach, chociaż są one tu w pełni obecne; także samo rozróżnienie miejsc, w których wykonano zamieszczone $\mathrm{w}$ albumie fotografie, nie ma - $\mathrm{w}$ artystycznym założeniu autora $^{17}$ - większego znaczenia. Fotografie nie są podpisane, strony nie

16 Określenie zapożyczone od Krzysztofa Mecha; K. Mech, Wstęp, [w:] K. Tarnowski, Pragnienie metafizyczne, Kraków 2017.

${ }_{17} \mathrm{~W}$ wywiadzie dotyczącym albumu Push the Sky Away Zbierski stwierdza: „Pojedyncze obrazy nie mają ze sobą związku na poziomie rzeczywistości (czas, miejsce, grupa społeczna), ale na poziomie imaginacji (stany, »autorstwo«)”. W innym miejscu natomiast wyznaje: „»ja« jako autor łączę ze sobą obrazy, które określam jako spotkania bez umieszczania ich precyzyjnie na osi czasu”. Marcin 

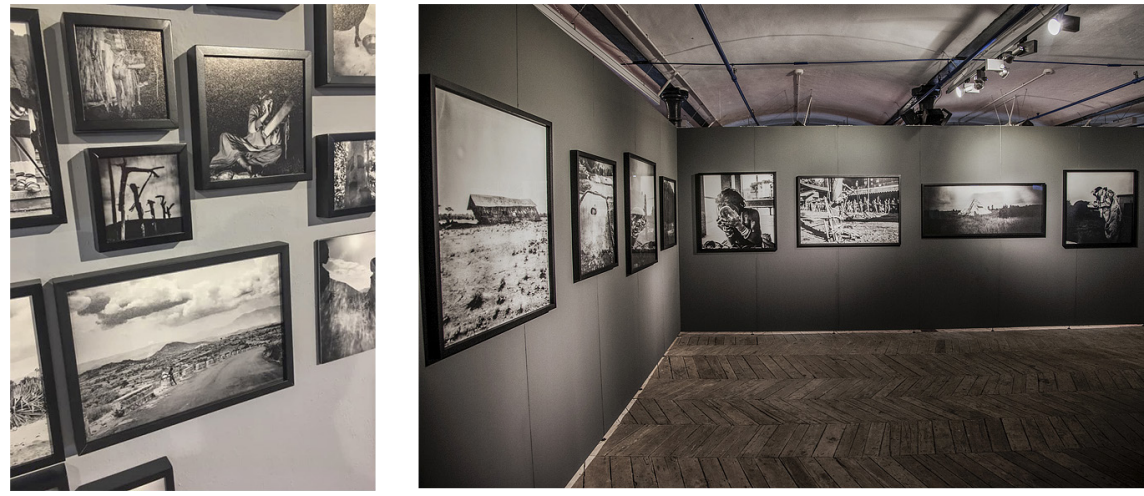

Il. 2-3. Fotografie Piotra Zbierskiego na Fotofestiwalu, Łódź 2019

mają numeracji (nawet na poziomie edytorskim), umykają przed łatwym wskazaniem miejsca - wymagają opisu w rodzaju: „o, ta fotografia pośrodku albumu, taki jasny (prześwietlony) krajobraz z Afryki, dziecko, chyba dziecko (?), rzuca czymś w kierunku rzeki, na fotografii jest jeszcze obraz na kalce, taki z ptakiem, którego ktoś/coś łapie czy wypuszcza, a może to ptak, który w proch się zamienia, a może z prochu powstaje" - oto możliwe deixis opisującego fotografie w Cieniach echa.

Jak pisałam na wstępie, sięgając po albumy z pracami Piotra Zbierskiego czy oglądając jego prace na wystawach, zawsze jestem w zawieszeniu w swego rodzaju poznawczym chaosie odczuć, skojarzeń i wiedzy - rozpięta między widzeniem, poznaniem, empirią, wiedzą a kryteriami estetycznymi. Zawarty w fotografiach ładunek emocjonalny (w tym egzystencjalny) zarówno na poziomie treści, jak i formy - sprawia, że moja relacja z nimi jest niczym swego rodzaju „obserwacja uczestnicząca”, korzystając tu przewrotnie $\mathrm{z}$ antropologicznej terminologii, nieobojętnej $\mathrm{w}$ toku niniejszych rozważań. I jest to w pewnym sensie jednocześnie obserwacja autora (przecież, jak często sam podkreśla, to jego opowieść o nim samym), obserwacja obrazów (samodzielnych bytów, w zaistniałych układach tworzących swoją subiektywną narrację) i obserwacja samej/samego siebie w relacji

Grabowiecki, Piotr Zbierski - rozmowa, 6.07.2012, https://www.fotopolis.pl/inspiracje/wywiady/13230-piotr-zbierski-rozmowa [dostęp 22.02.2020]. 
z tym, co właśnie postrzegane, a także z tym, co przeoczone. Treść staje się wtórnym konstruktem - w którym spotyka się subiektywność autora i subiektywność odbiorcy, obie zanurzone w określonym czasie i kulturze. Na pierwszym planie pozostaje jednak wrażenie - nastrój, prawie animistyczna wspólnota materii i treści. Jak powiedziałby Chris Wright: to, co nas tu uwodzi, to siła „antropologicznych klimatów”18, w tym przypadku zanurzonych w określonej estetyce, która - pomimo subtelnych uwag autora: to tylko „tło"19 - stanowi istotny element konstruowania znaczenia. Fotografia w swoim hermeneutycznym spojrzeniu jawi się tu jako przestrzeń między indywidualną ekspresją a rzeczywistością, będąc pytaniem o możliwość uchwycenia „widoku” świata. To fotografie, które z trudem kwalifikujemy jako realistyczne, pomimo świadomości realizmu samej zobrazowanej sytuacji i jej zapisu. Dodatkowo poprzez wybór techniki, a tym samym estetyki, uchwycone przez Zbierskiego obrazy wymykają się łatwej identyfikacji czasoprzestrzennej. To kolejny możliwy kontekst odczytania c zas jako jedno z możliwych „użądleń”, o których pisał Roland Barthes. Barthesowskie punctum może tu przynależeć zarówno do intensywności, jak i do formy ${ }^{20}$. Użycie technik analogowych, w tym m.in. aparatów małoobrazkowych, dominujące czerń i biel klasycznej fotografii, z jednoczesną intencjonalną niepoprawnością rejestracji oraz obróbki (błędy ekspozycji, skazy, plamy emulsji, dodatkowe efekty błędu skanera), wszystko to nie ułatwia racjonalnego rozpoznania. Zwłaszcza że czas jest tu mocno związany z niejednoznaczną siłą - chciałoby się rzec: przypadku, ale idąc tropem autora, raczej będzie to oddanie przestrzeni „prawom natury” ${ }^{21}$. Specyfika

${ }^{18}$ C. Wright, The Third Subject: Perspectives on Visual Anthropology, „Anthropology Today” 1998, Vol. 14, No. 4, s. 16-22, DOI: 10.2307/2783352.

19 Marcin Grabowiecki, Piotr Zbierski - rozmowa, op. cit.

20 R. Barthes, Światło obrazu. Uwagi o fotografii, tłum. J. Trznadel, Warszawa 1996, s. 160.

${ }^{21}$ W wywiadzie dla „Digital Camera” Zbierski podkreśla, że istotne jest dla niego przyzwolenie na rysowanie na zdjęciu czegoś dodatkowego: „[...] czegoś, co pochodzi z natury. Nie jest to przypadek, ale wpływ natury. Są to aparaty, które nie posiadają pewnych powłok, które powodują, w naszym rozumieniu, zakłócenia, w rozumieniu naturalnym - coś zupełnie normalnego. Bardzo cenię i szanuję wpływ miejsca na zdjęcie. To uwidacznia się chyba najbardziej w polaroidach, gdzie 
charakterystycznego dla Piotra Zbierskiego aktu fotografowania wynika m.in. z użycia aparatów, które zniekształcają obraz, np. analogowej Holgi, reklamowanej jako aparat „kreatywny i nieprzewidywalny”22. Prostota i niedociągnięcia konstrukcyjne tego amatorskiego aparatu nie pozwalają na wykonanie poprawnej, zgodnie z wytycznymi podręczników, fotografii: miejscowe prześwietlenia filmu (raz większe, raz mniejsze) czy niepowtarzalność ujęć są tu, poprzez wybór narzędzia, częścią kreacji. Wymykając się mechanizmom intencjonalnej inscenizacji, jednocześnie sugerują istnienie czegoś „ponad”: na zupełnie innym poziomie - zawieszone między realnie widocznym a przeżywanym - ujawniają „niewidoczne”. W tym przypadku swoiste "ponad" staje się dominującym czynnikiem nie tylko w hermeneutyczności samej fotografii, ale i mojego jej odczytania. Odwołując się ponownie do Barthes'a, moją świadomością potrząsają tu trzy czasy: mój teraźniejszy, czas fotografa ${ }^{23} \mathrm{i}$ jakby metafizyczny czas obrazu nakładający się na niejednoznaczność czasu realnego. Wpisane w fotograficzne zapisy swego rodzaju „tu i teraz” (fotografie wykonano w trakcie podróży w ciągu ostatnich sześciu lat) przynależy jednocześnie do jakiegoś „kiedyś”, równocześnie pozwalając stanąć „ponad”, dotrzeć do tego, co nam wszystkim wspólne, gdzie - jak głosi motto albumu - różnica między przeszłością, teraźniejszością i przyszłością jest tylko iluzoryczna. Obrazy te wprawiają nas w poznawcze zakłopotanie wynikłe z obcowania z czymś na kształt „współobecności czasów”, jak określa to sam autor:

To co interesuje mnie najbardziej w cyklu, to ślady i szwy tego, co było jeszcze przed obrazem, archeologia, która nie jest linearną rekonstrukcją, ale uznaniem współobecności czasów. Dialog pomiędzy czasem mentalnym i wspólnym, relacje z przeszłością. Interesuje mnie nachodzenie się i erozja natury oraz kultury, dążące do wyodrębnienia struktury, która pyta o to,

wilgotność i temperatura wpływają bezpośrednio na obraz"; Marcin Grabowiecki, Piotr Zbierski - rozmowa, op. cit.

22 „Lubię używać aparatów, które zniekształcają obraz, by w trakcie wykonywania zdjęcia robić wszystko, by obraz nie uległ całkowitemu zanikowi. Potrzebuje tego rodzaju balansu"; ibidem.

${ }^{23}$ R. Barthes, op. cit., s. 162. 
skąd przyszła; istnieje teraz, lecz jest wynikiem antropologicznej przeprawy przez wieki. Istnieje teraz, lecz cała pokryta jest kurzem przodków ${ }^{24}$.

Fotografie z albumu Echoes Shades nieustająco odsyłają nas do innego porządku czasowego. Przykucniętego w zrujnowanym budynku Hindusa i jego dwie krowy czy dziwne palenisko z głową bawoła z podążającym gdzieś w tle rzędem kobiet mógł sfotografować w latach 40. Henri Cartier-Bresson, skok przez krowy młodych członków plemienia Hamer z Doliny Omo może pochodzić ze zbioru opublikowanych w 1908 roku przez „The National Geographic Magazine” obrazów Afryki w cyklu „The National Timekeeper of Africa"25, podobnie jak rumuńskie dziewczęta mogłyby ilustrować majowy artykuł Where East Meets West $\mathrm{z}$ tego samego roku, a syberyjskie szałasy i renifery mogłaby uwiecznić Maria Czaplicka itd. Michał Dąbrowski - który na łamach Culture.pl zrecenzował pierwszy album Zbierskiego Push the Sky Away - zapewne uznałby te porównania za banalne i naiwne. Przecież wiemy, że tego typu „dokument z podróży” jest nieustannym wizualnym powielaniem pewnych kadrów, zwłaszcza w miejscach, które Historia umieściła jakby „poza czasem”, co podnosi ich dzisiejszą wizualną atrakcyjność i co ciągle jeszcze nas uwodzi. A dodatkowo jeśli wybierzemy odpowiednią technikę, to efekt jest z góry wiadomy. Nie są to przecież prawdziwe antropologiczne świadectwa, trudno mówić o jednoznacznej autodesygnacji, o uwierzytelnieniu czy o możliwości powtórzenia (cechach, za pomocą których Ricoeur określał funkcje dokumentu dostarczającego podstaw pamięci zbiorowej) ${ }^{26}$. W tym konkretnym przypadku - według Dąbrowskiego, który pisze z wyczuwalnym tonem ironicznym - „Archetypiczny Niewinny” fotografuje, poświęca czas na szukanie własnej drogi, próbuje się jednoczyć z Absolutem. I dalej:

${ }^{24}$ Czy natura może wspótistnieć z kulturą? Piotr Zbierski od 4 lat przemierza świat zgłębiając rytuały lokalnych społeczności, 29.01.2020, fotopolis; https://www. fotopolis.pl/newsy-sprzetowe/publikacje/33136-czy-natura-moze-wspolistniec-z-kultura-piotr-zbierski-od-4-lat-przemierza-swiat-zglebiajac-rytualy-lokalnych-spolecznosci [dostęp 5.03.2020].

25 „The National Geographic Magazine” 1908, Vol. 19, No. 1; https://archive. org/stream/nationalgeograp191908nati\#page/n27/mode/2up [dostęp 4.03.2020].

26 P. Ricoeur, Historia, pamięć, zapomnienie, cyt. za: M. Michałowska, op. cit., s. 252. 
Takim niewinnym w sztuce był Paul Gauguin, malarz francuski, który zrezygnował z pracy biurowej i wyjechał na Tahiti, by utrwalić na obrazach ludzi nieskażonych cywilizacją zachodnią. To wtedy stworzył pracę Skąd przyszliśmy? Kim jesteśmy? Dokąd idziemy? (1897)27.

„Archetypiczny Niewinny” powtarza gest naiwnej i jednocześnie wartościującej tęsknoty za metafizyką Noble Savage („szlachetnego dzikusa”), wyrusza w podróż, poszukuje tego, co metafizyczne, odnajduje uniwersalne prawdy, w tym tę o osobistym samoodkryciu w spotkaniu z Innym. $\mathrm{Na}$ ile współcześnie jest w tym niewinny bądź nieświadomy wszystkich towarzyszących takiej podróży kontekstom kulturowym czy społecznym, nie sposób jednoznacznie orzec (i takie orzekanie nie jest też konieczne). Drugi „niewinny” ogląda i nie może się powstrzymać, żeby nie wyruszyć, tym razem w zapośredniczoną, podróż wizualną, zadając sobie przy tym pytania Gauguina. Czy naprawdę straciły na wartości, jak bardzo stały się naiwne czy może - akurat $\mathrm{w}$ tym rozpatrywanym przypadku - obciążone dodatkowym, postkolonialnym kontekstem?

Oglądając album - czytam znaki, podążam za narracją. Zadaję sobie pytanie o sens samego oglądania, a także o moje prawo do patrzenia. Zatrzymuję się. Tropię szczegóły. Poddaję się wrażeniom. Spotykam się z Innym (i pytam o sens tego spotkania, i nie czuję się w nim niewinna). Idę wydeptanymi ścieżkami, jak i buduję nowe, w tym te indywidualne, wmontowane w mechanizmy pamięci i konteksty - także te, które mnie zaskoczyły. Interpretuję, a tym samym definiuję, narzucam obrazom odczytanie (chociaż jednocześnie chciałabym od tego uciec). Takie prawo wizualnego eseju i jego interpretacji. Oglądam i zastanawiam się, w jakim kierunku idzie moje przyporządkowanie znaczeń. Jaką rzeczywistość wizualną ja - odbiorca konstruuję, w jakiej pułapce moich narracji zamykam te obrazy i utrwalonych w nich ludzi. Tym samym stawiam pytanie o „niewinność” mnie jako patrzącego na Innych. O moje wizualne doświadczenie patrzenia na to, co nie-doświadczone, zobaczone i przeżyte w zapośredniczeniu - w przyjęciu cudzych obrazów, narracji, idei. Pytam o moją wizualną pamięć obrazów naocznych, jak i wyobrażonych. Tu - nie tylko w oglądzie zewnętrznym, ale także w tym wewnętrznym - też są rozmazania, plamy i niepoddająca

27 M. Dąbrowski, Piotr Zbierski, „Push the Sky Away”, Culture.pl; https://culture. $\mathrm{pl} / \mathrm{pl} / \mathrm{dzielo/piotr-zbierski-push-the-sky-away} \mathrm{[dostęp} \mathrm{14.02.2020].}$ 
się rygorom poprawności narracja strumienia świadomości; jest także lęk, zakłopotanie tego, który patrzy i buduje narrację. Moja pamięć nakłada się na pamięć obrazów z Echoes Shades. Nie jestem etnografem, ale - przypominając słowa Claude’a Lévi-Straussa - jest dla mnie ważne, na ile moje pełne przesądów „ja” staje się w doświadczeniu (niekoniecznie etnograficznym) przyrządem obserwacyjnym uzbrojonym we współczesna technologię i na ile musi niewątpliwie nauczyć się poznawać siebie samego... i swoje reakcje (ja/moje odczucia i to, co przyswoiłam są granicą tego, co widzę) w bezpośrednim kontakcie z własną naturą w jej pierwotnym wymiarze, bez lęku przed nostalgiczną ucieczką ${ }^{28}$.

Fotografowanie to dla Piotra Zbierskiego bezpośrednie spotkanie z Innym i jednoczesne doświadczanie siebie w tym spotkaniu. Dla odbiorcy to obecność Innego, zarówno tego, który stoi za aparatem, jak i tego utrwalonego - w taki, a nie inny sposób - na fotografii, i to na fotografii, która zawsze jest równocześnie konkretna i nieokreślona. Ta dialektyczność tkwi także w samym spotkaniu-patrzeniu, gdzie Inny raz jest Obcym, innym razem Levinasowską epifanią le visage, moją konfrontacją z „człowieczeństwem”, wezwaniem do „odpowiedzialności”29... Oto spoglądam w oczy wyłaniającego się spoza kadru dziecka (il. 4). Patrzymy na siebie nawzajem. Widzę jego ciekawość, chyba coś mówi? Nie mogę się powstrzymać przed skojarzeniem, że jest z innej rzeczywistości, podobnie jak jednoroga krowa, która też na mnie spogląda. Może to wpływ fotografii na poprzednich stronach. Zanurzonych w czystej czerni dzieci bujających się na drzewie, zestawionych z wyłaniającymi się z mroku, groźnie spoglądającymi twarzami „totemów” (to nic, że są z innego geograficznie obszaru). I znów na kolejnej stronie dwoje dzieci siedzi na uschniętym drzewie, trzecie gdzieś biegnie, otacza je bezgraniczna pustka mglisto-szarego krajobrazu (il. 5). Czerń, biel, nieostrość, mrok, niedoświetlenie, innym razem prześwietlenia rysujące tajemnicze linie i rozwarstwiające przestrzeń, wprowadzają swój

28 Zob. C. Lévi-Strauss, Jan Jakub Rousseau - twórca nauk humanistycznych, tłum. L. Kolankiewicz, „Twórczość” 1984, nr 6; zob. też omówienie w: J. Dziewit, A. Pisarek, op. cit., s. 14.

29 E. Levinas, Całość i nieskończoność. Esej o zewnętrzności, tłum. M. Kowalska, Warszawa 1998. 


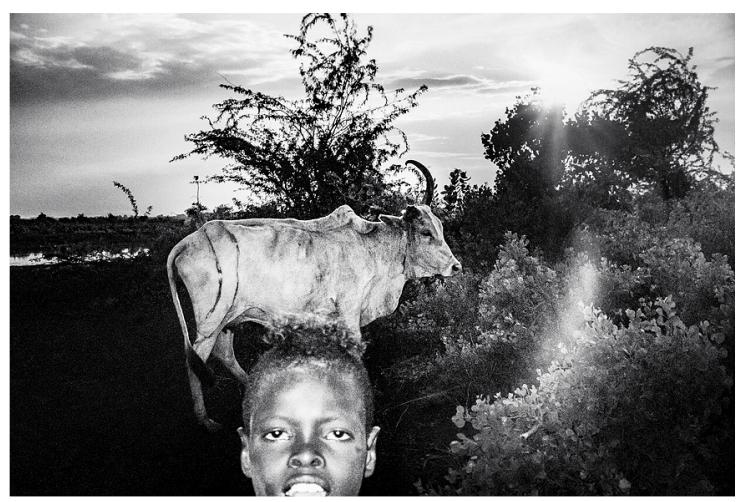

Il. 4. Fotografia z albumu Piotra Zbierskiego Echoes Shades (2020)

porządek odczytania. Budzą niepokój tajemnicy ${ }^{30}$. Są wejściem w rytuał, w którym treść i forma pozostają nierozerwalne, ale to forma ujawnia lub ukrywa to, co transcendentne.

Większość fotografii wykonanych przez Zbierskiego w Afryce bądź na Syberii wprowadza (czy też narzuca) ten dodatkowy poziom odczytania. Tak jak na opisanych przed chwilą fotografiach specyficzne mocne kontrasty, innym razem gęsty, można by powiedzieć: „pierwotny” mrok niskiej ekspozycji odsyłają do archetypicznego lęku przed ciemnością, strachu, który odnajdziemy w mitach większości kultur czy w antropologicznych opisach wierzeń i rytuałów. Mrok jest granicą widzenia. W mroku ujawnia się to, co przychodzi „spoza” rozpoznania i nazwania. Opisane dzieci raz wyłaniają się z ciemności, innym razem skryte są za czymś w rodzaju powidoku prześwietlenia. To spotkanie z Innym, które wychodzi poza zwykłą konfrontację. Suche drzewo ma w sobie coś monumentalnego i symbolicznego zarazem - jakby wpisuje się w wyobrażenie archetypu drzewa (o którym m.in. pisał

${ }^{30} \mathrm{~W}$ psychologii wyodrębniono rodzaj strachu wynikający nie z lęku przed realnym zagrożeniem, lecz mający swoje źródło w tzw. drugim układzie sygnałów; chodzi tutaj o wszystkie zniekształcenia, które to, co zwykłe (codzienne), przedstawia jako niebezpieczne - na ten rodzaj strachu składa się wszystko, co przyswajamy z otoczenia w trakcie naszej socjalizacji, a więc to, co wytwarza w nas kultura; por. S. Gerstmann, H. Orlikowska, I. Stachnikówna, Z badań nad psychologią strachu, Poznań 1957, s. 90-93. 


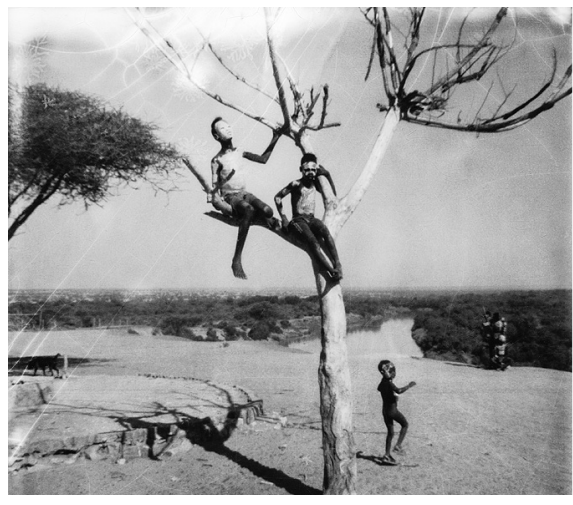

Il. 5. Fotografia $z$ albumu Piotra Zbierskiego Echoes Shades (2020)

Jung $^{31}$ ), a siedzące na Kosmicznym Drzewie dzieci, podkreślone wizualną formą fotografii, sprawiają wrażenie symbolicznych bytów „pomiędzy”; niczym „dusze” czy też istoty „demoniczne” nie przynależą ani do tej samej przestrzeni, ani do czasu. Czekają na prawo dotknięcia ziemi.

Wchodzę w „realne” - nie wiem, czy nagość i nędza (w Levinasowskim ujęciu) zbliżają mnie do Innego, ale budzą moją potrzebę mowy i ekspresji (choćby tej skierowanej do wnętrza). Kierują ku kontekstom istotnym dla mnie - przestaję być „niewinna”, wiem, w jakim kierunku podąża moja uciekająca w „symboliczne” narracja. Widzę dzieci na drzewie i jednocześnie wiem, że dzieci w Dolinie Omo mogą naprawdę zostać uznane za demony, te, które sprowadzają nieszczęście na rodzinę i całą wspólnotę (od razu też myślę o obecnej w albumie fotografii drzewa $\mathrm{z}$ dziuplami z indonezyjskiej prowincji Tana Toraja ${ }^{32}$ ) - to już nie jest nie-

${ }^{31}$ Motyw Kosmicznego Drzewa (określanego także mianem „Drzewa Świat”, według kosmogonii skandynawskiej - Yggdrasil) jako swoistego axis mundi odnajdujemy w licznych wierzeniach ludów rozproszonych na wszystkich zamieszkanych kontynentach. Motyw ten, jako jeden $\mathrm{z}$ archetypów, wielokrotnie pojawia się w pracach Junga (m.in. w Analizie marzeń sennych czy w Życiu symbolicznym), jak i później u Eliadego. Według Junga w myśleniu archaicznym poprzez drzewa czy zwierzęta objawia się swoista „dusza buszu” czy „duch przodka”; drzewo to także zarówno symbol kultu Wielkiej Matki (narodzin czy prapoczątku), jak i symbol „męskiej zasady życia”, zob. C.G. Jung, op. cit., s. 231, 267 i 283.

32 Gdy tylko z rozmowy z Piotrem Zbierskim dowiedziałam się, co konkretnie przedstawia drzewo $\mathrm{z}$ dziuplami, od razu miałam potrzebę weryfikacji samej tradycji. Według dawnych zwyczajów Tana Toraja dzieci, które urodziły się martwe lub zmarły przed szóstym miesiącem życia, chowane były w wydrążonych w drzewie dziuplach. Jest to związane $\mathrm{z}$ wierzeniami, w których dzieci do pojawienia się pierwszych zębów nie mogą dotknąć ziemi - do tego momentu jeszcze nie w pełni 
dookreślony, może archetypiczny lęk, to nie jest porządek mitu. Wiem, dlaczego przyszło mi to do głowy, i wiem też, skąd to wiem - czytałam i widziałam dokumenty i fabuły, nie tylko te dotyczące Etiopii (przez fotografię przebijają się powidoki obrazów afrykańskich „obozów dla czarownic”). W tym przypomnieniu kolejny raz uderza mnie okrucieństwo sięgających tysięcy lat wierzeń, a przede wszystkim ich obecność „tu i teraz”. Jestem pomiędzy świadomością „ich” lęku przed innością, tym, co nieznane, a moim - indywidualnym, jak i kulturowym - lękiem przed tym, co dla mnie inne i nieznane, a w tym przypadku przede wszystkim pierwotne - „dzikie”.

I tu staję przed kolejnym pytaniem: kiedy po raz pierwszy zobaczyłam „dzikiego"? ${ }^{33}$ Pytam sama siebie o pozycję mojego spojrzenia i mojej narracji. Przez moje myśli przelatują: Jądro ciemności, Czekając na barbarzyńców, wierszyk o Murzynku Bambo, Król Maciuś Pierwszy..., głupie dowcipy, pocztówki z „ludzkiego zoo”, filmy, media społecznościowe czy katalogi podróżnicze, pełne niezwykłych, barwnych obrazów zachwycających pierwotnym pięknem i dzikością Doliny Omo, a także strach o to, że już za chwilę ten istniejący pozornie „poza czasem” świat przestanie istnieć, zawłaszczony przez chińskie czy saudyjskie plantacje cukrowe (gdzieś o tym przeczytałam).

Wiem też, dlaczego to suche drzewo tak łatwo może stać się swoistym symbolicznym Kosmicznym Drzewem w „środku świata”, miejscem, które łączy zaświaty z Ziemią i Niebem. Wiem też, że to susza, która ma swoje dramatyczne konsekwencje (głód, migracje, wojny, śmierć). To moje konteksty

przynależą do świata żywych i mogą przemienić się w przynoszące nieszczęście demony. $Z$ czasem rozrastające się drzewa w pewnym sensie pochłaniają pochowane tam zwłoki dzieci, a wydrążone dziuple, najpierw zabezpieczone prowizorycznymi drzwiczkami, stopniowo zarastają korą. Drzewa i dziecięce dusze odnajdziemy też w tradycji syberyjskiej - na gałęziach niebiańskiego drzewa siedzą dusze dzieci i czekają, aż przyjdzie szaman i sprowadzi je na ziemię; zob. P. Kowalski, Leksykon znaki świata, Warszawa - Wrocław 1998, s. 95.

${ }_{33}$ Nawiązanie do pytania postawionego przez Hannę Schreiber (tekst często wykorzystuję na zajęciach m.in. w kontekście analizy Jądra Ciemności J. Conrada czy na zajęciach poruszających konteksty fotografii i antropologii wizualnej), zob. H. Schreiber, Ludzkie zoo, „Społeczeństwo i Polityka” 2014, nr 1-2. 
i moja ambiwalencja odczuć. Tych, które przyłapałam na współistnieniu z moim patrzeniem i widzeniem. Tu i teraz.

Nigdy nie byłam w Afryce, mam tylko zbiór jej przedstawień wizualnych bądź literackich, a także tych naukowych czy może bardziej: popularnonaukowych. Ale chcąc zbliżyć się do swoistej epifanii spotkania - tej niemożliwej w szybkim, wernakularnym oglądzie (N. Mirzoeff) ${ }^{34}$ - skonfrontować spojrzenia (przecież, przywołując stwierdzenie Waltera Benjamina odnoszące się do pierwszych reakcji na dagerotypy, ja i postać z fotografii „patrzymy” sobie w oczy i możemy siebie „widzieć” $)^{35}$.

Obrazy mojej pamięci przywołują widok z dzieciństwa, spędzane na wsi wakacje i całodniowe wysiadywanie grupy dzieci na trzech oddalonych od zabudowań wierzbach - były naszym światem, świadkiem spotkań, rozmów, zabaw... (i nie raz słyszeliśmy, że siedzimy na nich niczym strzygi). Są obrazem dzieciństwa: mojego, tego afrykańskiego i tego z Indonezji. Mam punkt zaczepienia, przez który odczuwam swoistą wspólnotę. Dzieci siedzące na drzewach czy na różnych konstrukcjach (np. trzepakach) pojawiają się w albumie na kilku fotografiach. Symbolicznie łączą kultury i ujawniają swój odwieczny rytuał, pierwotną wspólnotę zachowań, zawieszenie między sacrum a profanum ${ }^{36}$.

Kartkując album, coraz głębiej wchodzę zarówno w ten kulturowy, jak i własny porządek symboliczny. Każda percepcja, co podkreślał już Henri

${ }^{34}$ N. Mirzoeff, Jak zobaczyć świat, tłum. Ł. Zaremba, Kraków - Warszawa 2016.

${ }^{35}$ W. Benjamin, Mała historia fotografii, tłum. J. Sikorski, [w:] idem, Anioł historii. Eseje, szkice, fragmenty, wyb. i oprac. H. Orłowski, Poznań 1996.

36 Przykładowo: Giorgio Agamben wskazuje genezę większości dziecięcych zabaw m.in. w starych religijnych rytuałach; $w$ takim ujęciu zabawa pełni w kulturze funkcję rezerwuaru znaczeń, i jest swego rodzaju „połowicznym wykonaniem czynności sakralnej" - wyzwala z sacrum, nie obalając go (zob. G. Agamben, Profanacje, tłumł. M. Kwaterko, Warszawa 2006). Związki dziecięcych zabaw i sacrum zob. także: M. Śnieciński, Cywilizacja spektaklu - profanacje i gra zmystów, „Dyskurs” 2012, nr 13/14, s. 209, http://cejsh.icm.edu.pl/cejsh/element/bwmetal.element.desklight-578b5ade-0ead-40b2-a7cd-5797c97bbaf6; O. Kłosiewicz, W chowanego z rozumem, „Dyskurs” 2012, nr 13/14, s. 8-41, https://www.asp.wroc.pl/dyskurs/ Dyskurs1314/OlgaKlosiewicz.pdf [dostęp 16.07.2019]. 
Bergson, jest nasycona wspomnieniami - z bezpośrednimi i aktualnymi danymi naszych zmysłów mieszamy nieskończoną ilość detali z przeszłego doświadczenia; wspomnienia te mogą zajmować miejsce rzeczywistych percepcji, z których zachowujemy tylko kilka wskazań ${ }^{37}$. Pamięć ingeruje w percepcję, modyfikuje ją i może też - jak pisze Filip Lipiński - „uzupełniać, ale i osłabiać wyrazistość naocznego obrazu. Pozwala ona na płynność czasu - trwanie, przejście z jednego postrzeżenia w drugie bez wyraźnej cezury” ${ }^{38}$. Ujawnia także moją „kolektywną” podmiotowość, moją świadomość i - dodając za Jungiem - nieświadomość zbiorową, przynależącą do mojej („odziedziczonej”) struktury osobniczej39. Ujęta w obrazy „tęsknota za mitem”, za którą podąża Zbierski, jest także moją, a zarazem ogólnoludzką tęsknotą.

Patrząc na fotografie (nie tylko te), na utrwalone w nich elementy ożywionego i nieożywionego świata, czuję, że są czymś więcej niż tym, co może być dostrzeżone. Akt twórczy i jego materia nadają mu charakter szamańskiego rytuału. Pozwalają przywołać także to, co w pierwszym oglądzie niewidoczne. W metafizycznym wykraczaniu „poza” pytamy o sens - powracamy do pytań Gauguina, do punktu wyjścia, do pytania o sens bytu, o życie naznaczone śmiercią, o bycie sobą, o wymiary nadziei, do pytania o sens pierwotny i o wolność. Banał... Proste ćwiczenia z filozofii bytu, na równi istotne, jak i „niefunkcjonalne”, w szczególności w zderzeniu ze współczesną faktycznością, w tym z jej technologicznym podążaniem za idealnie ostrą wizją świata.

Egzystencjalny lęk, oswajany przez różne formy rytuałów przejścia, nie jest nam kulturowo obcy, chociaż spychamy go na obrzeża naszej codzienności, skrywamy za technologią. Dziwią nas tym samym i wzbudzają mocno mieszane uczucia (u niektórych zapewne także wstręt) obrazy utrwalone na

${ }^{37}$ H. Bergson, Materia i pamięć. Esej o stosunku ciała do ducha, tłum. R.J. Weksler-Waszkinel, Kraków 2006, s. 27.

${ }_{38}$ F. Lipiński, Figuracje pamięci w wirtualnym polu (historii) sztuki, „RIHA Journal" 2014, Special Issue: Contemporary Art and Memory, http://www.riha-journal.org/articles/2014/2014-oct-dec/special-issue-contemporary-art-and-memory-part-1/lipinski-figurations-of-memory- [dostęp 1.02.2020].

39 C.G. Jung, Analiza marzeń sennych. Według notatek z seminariów 1928-1930, tłum. R. Reszke, Warszawa 2015, s. 177. 
indonezyjskiej wyspie Sulawesi. Kult śmierci w pewnym sensie przerasta tam życie - i to w bardzo szerokim znaczeniu określenia „przerasta”. W fotografiach z tego cyklu Piotr Zbierski nie stara się epatować klasycznymi widokami (często utrwalanymi w tym miejscu przez podróżników-turystów), ale także nie może przed nimi uciec ${ }^{40}$. Czy jest dalekim obserwatorem, czy wchodzi w rodzaj współuczestnictwa w rytuale, utrwala widoki bardzo odległe od współczesnego nam rozumienia pochówku i pamięci o zmarłych (istotnej także w naszej kulturze). Zasuszone mumie przodków są tu częścią życia. Wyrwane z kontekstu kulturowego tradycyjne zachowania - jak i sama ich forma - dziwią na różnych poziomach. Zbierskiemu udało się je oswoić. Ukazał przez pryzmat tamtejszej codzienności, i to dosłownie w kilku ujęciach, swoistą symbiozę życia i śmierci ${ }^{41}$. Zachodnie tabu martwego ciała podlega tu oswojeniu, przez konteksty i ludzkie emocje. Nie musimy znać całości sulaweskich rytuałów - w omiataniu ciała wielką szczotką, raz pełnym powagi, raz w radosnych emocjach, widzimy „różnice” i „powtórzenie”.

W jednym kadrze mieści się to, co nas oddala i zbliża - w rozumieniu i w emocjach. Ktoś trzyma odświętnie przybraną w nowe ubranie, w tym czapkę z daszkiem, okrytą czystą narzutą mumię kogoś bliskiego, obok radośnie uśmiechnięta dziewczyna także trzyma mumię (il. 6). Możliwe, że wchodzą do domu, pozwalają zmarłym, o których pamiętają i o których dbają, współuczestniczyć w swoim życiu. Nie jest to ich codzienność, to powtarzany co roku sierpniowy rytuał, chroniący przed zapomnieniem tak żywych, jak i umarłych, będący wyrazem ich wzajemnej opieki. Na innej fotografii zamyślony mężczyzna (wydaje się nieco skrępowany obecnością

40 Nie można tu pominąć faktu, że w wielu wypadkach fotografia turystyczna może być symbolicznym narzędziem przemocy i panowania, tak jak miało to miejsce w trakcie fotografowania ludzkich zoo. Często w takich przypadkach - jak pisze Paweł Cywiński - zdjęcie staje się ważniejsze niż człowiek. Jego destrukcyjna siła drzemie w tym, że uchodzi za miniaturę rzeczywistości, a nie produkt kulturowy czy ideologiczny. Traktowane jest jako fragment świata, jako prawda - a nie komentarz; P. Cywiński, Ludzkie zoo, „Magazyn Kontakt”, 14.05.2012, https:// magazynkontakt.pl/ludzkie-zoo/ [dostęp 2.03.2020].

${ }^{41}$ Więcej fotografii z tego cyklu, jak i materiał filmowy dostępny jest na stronie: https://vimeo.com/350656912 [dostęp 2.03.2020]. 
fotografa) stoi z mumią swojego ojca $^{42}$. Wcześniej oczyszczał ją, może z kurzu, może z pajęczyn. $\mathrm{Na}$ kolejnej fotografii przebrane w nową odzież dwie mumie stoją oparte o ozdobne wejście - są niczym postacie z popularnego obrazu Paola Vincenza Bonominiego Małżonkowie (1810): to także obraz małżonków, ale $\mathrm{w}$ tym przypadku nie stanowią symbolu nieuchronności śmierci, ale życia i wspólnoty. $\mathrm{Na}$ jeszcze innej - przy wejściu do kamiennego grobowca stoi drewniana podobizna zmarłego (tau

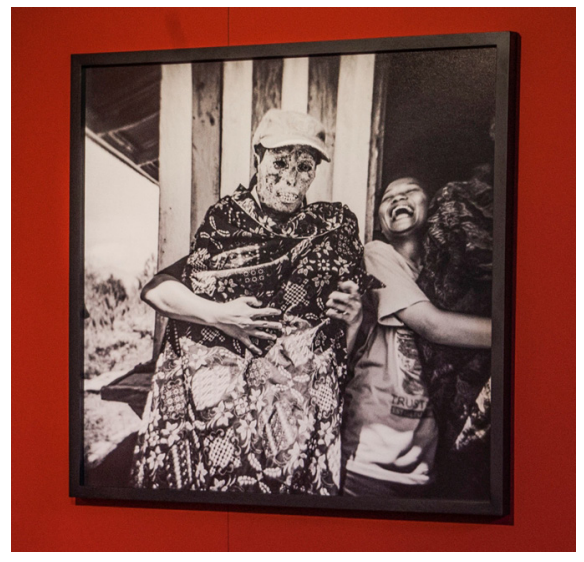

Il. 6. Fotografia $z$ albumu Piotra Zbierskiego Echoes Shades (2020), prezentacja na wystawie tau) i jego oprawiona $\mathrm{w}$ ramkę, zniszczona upływem czasu fotografia (il. 7). Również tu, jak w większości fotografii Zbierskiego, sama nieostra i prześwietlona materia obrazu nie ułatwia rozpoznania; i ten zmaterializowany zapis pamięci podlega zniekształceniom. Dlatego też - powiedzieliby mieszkańcy Tana Toraja - trzeba sobie przypominać.

Figury tau tau, które przedstawiają zmarłych przodków, nie tylko utrwalają ich obraz, lecz i chronią: zmarłych, ich grobowce, ale i żywych przed złymi duchami. Uwieczniony wizerunek (choćby symboliczny, naszkicowany na kawałku drewna; chociaż z czasem odwzorowania te stawały się coraz bardziej drobiazgowe) chroni przed „niebytem”, pozwala pozostać cząstką wspólnoty, być z nią i ją chronić. Mumie w przypisanym sobie procesie

${ }^{42}$ Z rozmowy z Piotrem Zbierskim wiem, że mężczyzna z dumą prezentował mumię ojca, okazując jej tym samym troskę. Obecność fotografa nie jest w tym przypadku formą wtargnięcia, jest wynikiem zaproszenia do udziału w rodzinnym święcie. Wyjmowane z grobów mumie przodków często wraz z rodziną "pozują" do kolejnych fotografii, a dzięki mediom społecznościowym ich wizerunki docierają do rozproszonych po świecie członków rodziny. Takie wspólne „pozowanie” możemy zobaczyć m.in. w jednym z odcinków serialu dokumentalnego Rytuały (Rituals) (BBC, Wielka Brytania 2017). 


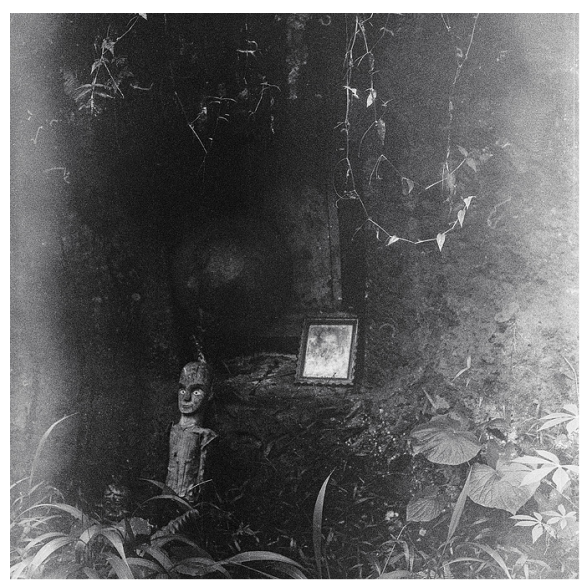

Il. 7. Fotografia $z$ albumu Piotra Zbierskiego Echoes Shades (2020)

ulegną rozpadowi, ich wizerunek zatrze się, figura tau tau przetrwa dłużej. A niepewna materia fotografii jest tu tylko uzupełnieniem.

$\mathrm{Z}$ kolejnych stron albumu spoglądają na nas dziwne kopie moai, posągi zdolne do przechwytywania many, stroje i szamańskie bębny. Mana przemieszcza się z przedmiotu w przedmiot. I nie ma tu znaczenia, czy to rytuał polinezyjski, syberyjski, afrykański czy podlaski. Przemieszane fotografie oddają wspólnotę pierwotnych potrzeb kontaktu $\mathrm{z}$ tym, co transcendentne (il. 8).

Na sąsiadujących ze sobą stronach, jakby obok moai, syberyjscy szamani wchodzą w trans i łączą się ze światem duchów. Proszą ich o wsparcie, opiekę, uzdrowienie, ochronę przed demonami. Indonezyjskie dzieci siedzą na grobowcu, afrykańskie kryją się w „cieniu” drzew, syberyjskie bawią się przy szałasach, jeżdżą na reniferach, spacerują w tundrze (a może to łąka na Podlasiu?), rzucają w rytualnym geście ciastka - pokarm dzieci i duchów (dodatkowo warto przyjrzeć się, na ilu fotografiach widać ofiarne ciastka). Rytuał i codzienność są tu nie tylko wizualną wspólnotą; jak pisał francuski etnolog Arnold van Gennep: „życie jednostki nie stanowi continuum, ale jest serią symbolicznie naznaczanych »skoków«, względnie "przejść«, wszechświat ulega rytmom znajdującym swoje odbicie w życiu społeczeństwa"43, a życie to nieustanne przekraczanie granic między sacrum a profanum ${ }^{44}$.

Antropologiczna opowieść Piotra Zbierskiego - nawet jeśli nie do końca intencjonalnie - skupia się na znakach mocno uniwersalnych i, zwłaszcza w przeszłości, czytelnych w wymiarze symbolicznym. Dziś dla wielu to raczej intuicyjne odczytanie, czasem skrywane pod rozpoznaniem popularnego

${ }^{43}$ Za: W.J. Burszta, Antropologia kultury, Poznań 1998, s. 104.

44 Cyt. za: K. Motyl, Rytuat - od antropologii kulturowej do analizy transakcyjnej, „Edukacyjna Analiza Transakcyjna” 2014, nr 3, s. 70. 


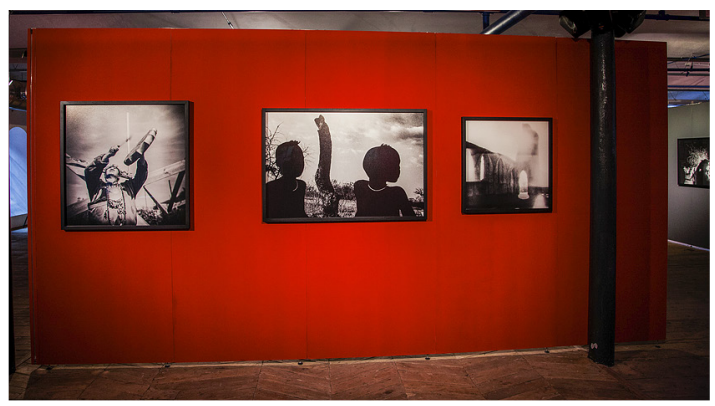

Il. 8. Fotografie Piotra Zbierskiego na Fotofestiwalu, Łódź 2019

motywu - samotnego drzewa, pustkowia, zwierząt... Bez potrzeby odpowiedzi, co takiego jest w tych drzewach, w jeleniach (renach) czy w melancholijnych krajobrazach, że tak często stanowiły i stanowią treść obrazów. Czy jak pytał, idąc tropem myśli Junga, Eliade: na jaką potrzebę odpowiadają te mity, symbole i obrazy, że tak się rozpowszechniły? ${ }^{45}$ I nawet jeśli pytania te wprowadzają nas na ścieżkę nadinterpretacji, to wejście na nią otwiera narracyjne związki raz wspólnych, raz krzyżujących się i rozwidlających ścieżek opowieści. Jak podkreślał Eliade, obrazy-symbole odpowiadają na naszą wewnętrzną potrzebę: „każda istota historyczna nosi w sobie dużą część człowieczeństwa sprzed Historii ${ }^{346}$. A każde indywidualne poznanie, jak podkreślał Jung, jest właściwie rozpoznaniem (przypomnieniem): „zewnętrzna sytuacja budzi w duszy ludzkiej odpowiadający jej archetyp jako skarbiec doświadczeń", a obecne w nas ślady ducha archaicznego są tym miejscem, "gdzie człowiek przestaje być indywiduum odgraniczonym od innych, gdzie się rozprzestrzenia i stapia z istotą ludzkości”47.

Dzieci, tak często obecne na zebranych w albumie fotografiach, wpisane w metafizyczną opowieść i zestawione z pozostałymi obrazami, symbolizują sferę zawieszenia - pozostają w okresie przed wejściem do wspólnoty ${ }^{48}$. Są

${ }_{45}$ M. Eliade, Obrazy i symbole, op. cit., s. 39.

46 Ibidem, s. 15.

47 C.G. Jung, Życie symboliczne, op. cit., s. 6-57.

48 Dzieci przed rytuałami recepcyjnymi to np. „nieczyści zmarli”, którzy mogą się stać demonami - tego typu wierzenia odnajdziemy w większości kultur, od 
niewinne, ale i reprezentują to, co niejednoznaczne (amorficzność zaświatów), to, co nieuformowane ${ }^{49}$. Ich komunikacja/kontakt z tym, co nierzeczywiste, jest prosta i naturalna. Dzieci płaczące, jakby zawieszone w transie czy ukryte w mroku kontrastów i prześwietleń, siłą rzeczy - w szczególności przez przyjętą formę - wprowadzają nas w porządek mitu. Podobnie działają fotografie zwierząt: krowy czy jelenie (reny) na niektórych ujęciach mają w sobie coś monumentalnego. Wycięte kadrem z rzeczywistości, zawieszone w tajemniczej przestrzeni czy stojące na symbolicznym pustkowiu, uosabiają samo życie i wieczne odradzanie. Rogate zwierzęta, jak Kosmiczne Drzewo, łączą sfery Ziemi i Nieba. Uosabiają przemianę pór roku (gubienie rogów przez jeleniowate), ideę wiecznej zmiany i powrotu. Ich rogi (wiązane z bóstwami lunarnymi) są zarówno symbolem płodności, jak i stanowią apotropaiczny oręż do walki bądź odstraszania mocy demonicznych. Tak wykorzystywane poroża odnajdziemy i w tradycji syberyjskiej, i w afrykańskiej, w Indiach, w Ameryce Północnej, w europejskich obrzędach (jak choćby tych w Rumunii) czy w polskich domach nie tylko na Podlasiu, choć obecności samych poroży możemy w tym kontekście nie odczytać. Zawieszone w domu rogi dziś raczej nas straszą niż strzegą (są dla nas raczej źle kojarzonym myśliwskim trofeum i w wielu wypadkach realnie nim są). Podobnie powiązany od wieków z zasadami Wszechświata - z mocą, siłą i seksualnością - jeleń zatracił swoją symboliczną moc. Jednak na czarno-białej fotografii Zbierskiego, w kontekście całej narracji, choć na chwilę odzyskuje swoje mityczne znaczenie. Podobnie drzewa (te samotne, te, na których siedzą dzieci, te żywe i te martwe), w różnych, także wspominanych już kontekstach, są w albumie swoistym axis mundi. To na nich i wokół nich odbywają się różne rytuały - przejścia i inicjacji. Kosmiczne Drzewa w porządku mitu symbolizują Wszechświat i same są Wszechświatem, stanowią wyobrażenie o pełni i pozwalają na dotknięcie sacrum ${ }^{50}$. W drzewach bogowie objawiają swoją moc. Łącząc sfery - co symbolicznie oddaje umiesz-

europejskich po wierzenia Aborygenów. Obecnie w niektórych rejonach Afryki siła tych wierzeń stanowi zagrożenie dla dzieci, które znalazły się poza wspólnotą.

${ }_{9}$ Dzieci, według mitów obecnych w wielu kulturach, przybywają z głębi ziemi, z jaskiń, grot, z rzek czy bagnisk, wyrastają w roślinach, które wyrosły spod ziemi i mają z nią bezpośredni kontakt; zob. P. Kowalski, op. cit., s. 183.

50 Zob. ibidem, s. 97 i n. 
czona powyżej fotografia z Echoes Shades (il. 9) - Nieba (korona), Ziemi (pień) i Podziemia/Zaświatów (korzenie), są dla nas drogą kontaktu do tych wszystkich kręgów, które na co dzień nie są nam dostępne. Stąd obecny w tak wielu kulturach rytuał wspinania się na symbolizujące Kosmiczne Drzewo, ustawione w „środku świata” rytualne słupy. $\mathrm{Na}$ jednej z fotografii ktoś wspina się na słup - znika poza kadrem, jest w ,innej sferze”, tej dla nas niewidocznej, gdzie można zobaczyć przyszłośćs1. Obecne na wielu fo-

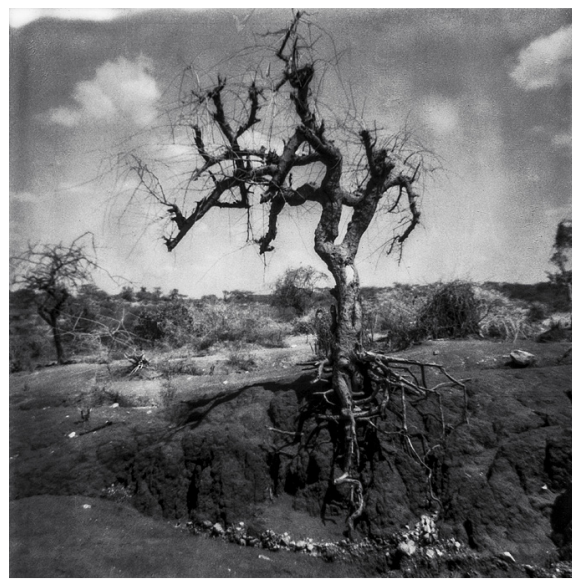

Il. 9. Fotografia $z$ albumu Piotra Zbierskiego Echoes Shades (2020) tografiach patyki, kije, drewniane rzeźby, totemy, zwłaszcza jeśli zostały wykonane z odpowiedniego drewna, mają siłę mediacyjną, pozwalają na dotarcie do tej innej, przynależnej duchom przestrzeni. Ich krzyżowanie, wyznaczanie granic, wbijanie w ziemię, uderzanie w nie, jak i ich palenie chroni nas przed zjadliwością demonów, wyznacza granicę, której nie mogą one przekroczyć, a w innych sytuacjach, w szamańskich rytuałach, daje możliwość kontaktu - wspomnianej mediacji - utrzymującej porządek świata. Istniejąc w porządku hierofanii, są jednocześnie tym, co symbolizuje sacrum, jak i sobą ${ }^{52}$. Warto się przyjrzeć, na jak wielu fotografiach odnajdziemy tego typu atrybuty.

Drzewo na pustkowiu dodatkowo wpisuje się w nie tylko metafizyczny, ale i ten mocno odczuwany w wymiarze egzystencjalnym lęk przed Nocą Kosmiczną, przed nieokreśloną, niepojętą nicością. Pustka jest tu jednocześnie Niebem i Piekłem. Stąd mit człowieka zagubionego na pustkowiu. Na jednym z umieszczonych w albumie kadrów pustkowie dosłownie przeżera czarna otchłań (il. 10). Na innym rozmyty obraz sam zamienia się w niebyt.

${ }^{51}$ Odwołanie do rytuałów wspinaczki jako dotknięcia Nieba (do którego w rytuałach szamańskich drzewa otwierają wejście) i uzyskania choćby na moment mocy profetycznej - zob. ibidem, s. 99 i n.

52 Zob. M. Eliade, Obrazy i symbole, op. cit., s. 208. 
W jeszcze innym przypadku obrazy zniszczonych budynków oddają moc pustki, opuszczenia i tym samym destrukcyjnej siły czasu. Czasu destrukcji czy śmierci, który jest jednocześnie czasem odnowy. W takim odbieraniu, czytaniu emocji bądź lęków - jak by powiedział Jung - nie ma nic mistycznego, wspólnota wyobrażeń nieświadomości zbiorowej jest zbiorem reliktów i wspomnień z przeszłości ${ }^{53}$.

Symbole, podobnie jak fotografia, powstają w procesie „stawania się” czas je tworzy, czas deformuje i czas je niszczy. Jednak niezależnie od nieustającego procesu „stawania się” mity (i wpisane weń obrazy) nie tracą na aktualności psychicznej - zmienia się tylko forma ${ }^{54}$ opowieści. Wspomniana

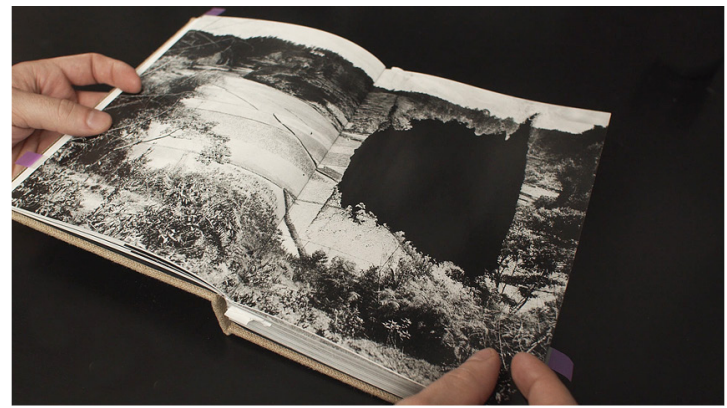

Il. 10. Fotografia - tzw. rozkładówka w albumie Piotra Zbierskiego Echoes Shades (2020)

we wstępie Elizabeth Edwards pisze o sile „uelastycznionej”, „multimedialnej” i „poruszającej” antropologii, otwartej na rozmaite formy ekspresji wizualnej (w tym eksperymenty). Znaczenie takich dokumentów wynika dla niej z tego, że twórcy tych obrazów kulturowych (dokumentów o kulturze) podejmują próbę zakomunikowania wartości i wiedzy o świecie wyrastających z ludzkiego doświadczenia i ludzkiej świadomości ${ }^{55}$. Dialog z tradycjami - czy to, jak w omawianym albumie, azjatyckimi, afrykańskimi, czy europejskimi - pozwala nam odkryć nasze duchowe podstawy, powrócić do zapomnianych czy zlekceważonych źródeł człowieczeństwa ${ }^{56}$.

53 C.G. Jung, Życie symboliczne, op. cit., s. 55.

54 M. Eliade, Mity, sny i misteria, tłum. K. Kocjan, Warszawa 1994, s. 18.

55 Cyt. za: K. Olechnicki, op. cit., s. 37.

56 M. Eliade, Mity, sny $i$ misteria, op. cit., s. 60. 
A sama recytacja (przywołanie/zobrazowanie) mitu - jak pisze Eliade - nie pozostaje bez konsekwencji dla tego, kto recytuje, i dla tego, kto go słucha ${ }^{57}$.

\section{Bibliografia}

Giorgio Agamben, Profanacje, tłum. M. Kwaterko, Państwowy Instytut Wydawniczy, Warszawa 2006.

Roland Barthes, Światło obrazu. Uwagi o fotografii, tłum. J. Trznadel, KR, Warszawa 1996.

Walter Benjamin, Mała historia fotografii, tłum. J. Sikorski, [w:] idem, Anioł historii. Eseje, szkice, fragmenty, wyb. i oprac. H. Orłowski, Wydawictwo Poznańskie, Poznań 1996.

Henri Bergson, Materia i pamięć. Esej o stosunku ciała do ducha, tłum. R.J. Weksler-Waszkinel, Zielona Sowa, Kraków 2006.

Wojciech J. Burszta, Antropologia kultury, Zysk i S-ka, Poznań 1998.

Paweł Cywiński, Ludzkie zoo, 14.05.2012, „Magazyn Kontakt”, https://magazynkontakt.pl/ludzkie-zoo/.

Czy natura może wspótistnieć z kulturą? Piotr Zbierski od 4 lat przemierza świat zgłębiając rytuały lokalnych społeczności, 29.01.2020, Fotopolis, https://www. fotopolis.pl/newsy-sprzetowe/publikacje/33136-czy-natura-moze-wspolistniec-z-kultura-piotr-zbierski-od-4-lat-przemierza-swiat-zglebiajac-rytualy-lokalnych-spolecznosci.

Michał Dąbrowski, Piotr Zbierski, „Push the Sky Away”, Culture.pl, https://culture. $\mathrm{pl} / \mathrm{pl} / \mathrm{dzielo} /$ piotr-zbierski-push-the-sky-away.

Jakub Dziewit, Adam Pisarek, Ciemnia antropologiczna, [w:] Patrzenie i widzenie w kontekstach kulturoznawczych, red. J. Dziewit, M. Kołodziej, A. Pisarek, grupakulturalna.pl, Katowice 2016.

Mircea Eliade, Mity, sny i misteria, tłum. K. Kocjan, KR, Warszawa 1994.

Mircea Eliade, Obrazy i symbole. Szkice o symbolizmie magiczno-religijnym, tłum.

M. i P. Rodakowie, KR, Warszawa 1998.

Mircea Eliade, Traktat o historii religii, tłum. J. Wierusz-Kowalski, Opus, Łódź 1993. Stanisław Gerstmann, Halina Orlikowska, Irena Stachnikówna, $Z$ badań nad psychologia strachu, PWN, Poznań 1957.

57 Idem, Obrazy i symbole, op. cit., s. 66. 
Carl Gustav Jung, Analiza marzeń sennych. Według notatek z seminariów 1928-1930, tłum. R. Reszke, KR, Warszawa 2015.

Carl Gustav Jung, Życie symboliczne, tłum. R. Reszke, KR, Warszawa 2007.

Olga Kłosiewicz, W chowanego z rozumem, „Dyskurs” 2012, nr 13/14, https://www. asp.wroc.pl/dyskurs/Dyskurs1314/OlgaKlosiewicz.pdf.

Piotr Kowalski, Leksykon znaki świata, WN PWN, Warszawa - Wrocław 1998.

Claude Lévi-Strauss, Jan Jakub Rousseau - twórca nauk humanistycznych, tłum.

L. Kolankiewicz, „Twórczość” 1984, nr 6.

Emmanuel Levinas, Całość i nieskończoność. Esej o zewnętrzności, tłum. M. Kowalska, WN PWN, Warszawa 1998.

Filip Lipiński, Figuracje pamięci $w$ wirtualnym polu (historii) sztuki, „RIHA Journal” 2014, Special Issue: Contemporary Art and Memory, http://www. riha-journal.org/articles/2014/2014-oct-dec/special-issue-contemporary-art-and-memory-part-1/lipinski-figurations -of-memory-en.

Marcin Grabowiecki, Piotr Zbierski - rozmowa, fotopolis, 6.07.2012, https://www. fotopolis.pl/inspiracje/wywiady/13230-piotr-zbierski-rozmowa.

Marcin Grabowiecki, Piotr Zbierski - rozmowa, „Digital Camera Polska” 2019, nr 6. Krzysztof Mech, Wstęp, [w:] K. Tarnowski, Pragnienie metafizyczne, SIW Znak, Kraków 2017.

Marianna Michałowska, Foto-teksty w badaniach historiograficznych - wokół refleksji Paula Ricoeura, „Dyskurs” 2011, nr 12, https://www.asp.wroc.pl/?module $=$ StaticContent\&controller=Main\&id=759\&__seoName=Dyskurs+12.

Nicholas Mirzoeff, Jak zobaczyć świat, tłum. Ł. Zaremba, Karakter - Muzeum Sztuki Nowoczesnej w Warszawie, Kraków - Warszawa 2016.

Karol Motyl, Rytuat - od antropologii kulturowej do analizy transakcyjnej, „Edukacyjna Analiza Transakcyjna” 2014, nr 3.

Krzysztof Olechnicki, Wartość estetyczna a poznanie naukowe w socjologii i antropologii obrazu, [w:] Co widać?, red. J. Kaczmarek, M. Krajewski, WN UAM, Poznań 2006.

Hanna Schreiber, Ludzkie zoo, „Społeczeństwo i Polityka” 2014, nr 1-2.

Marek Śnieciński, Cywilizacja spektaklu - profanacje i gra zmysłów, „Dyskurs” 2012, nr 13/14, http://cejsh.icm.edu.pl/cejsh/element/bwmetal.element. desklight-578b5ade-0ead-40b2-a7cd-5797c97bbaf6.

Chris Wright, The Third Subject: Perspectives on Visual Anthropology, „Anthropology Today" 1998, Vol. 14, No. 4, DOI: 10.2307/2783352. 


\section{Through the Recipient's Eyes: Eye Images and Imaginary Images. Piotr Zbierski's Echoes Shades Album}

This essay is a proposal of such an interpretation of an artistic project that constantly balances on the border of meanings arising, in this case, from the relationship (or even tensions) between the content, form and arrangement of photographs. Viewing the album is treated here as a task immersed in both scientific reflection and - referring to Carl Gustaw Jung - as experiencing (also that which escapes rationality) and feeling, as Mircea Eliade would say, as a pre-reflection grasp, and in addition, as Kantian Ehrfahrung also immersed in memory structures. Entering the ground of discursive spaces, related, among others to anthropology as well as symbolic reflection arising from the reception of the works of Jung and Eliade, is here above all, an impulse for analysis, one of the spaces for asking questions, expanding contexts and following one's own paths of associations and emotions, inevitably, dependent on both a professional and emotional view. The photographs gathered in the album entitled Echoes Shades (2020), taken over the past five years, illustrate the author's 'mystical' journey - his search for a 'common magical thinking' this time in the African Omo Valley, Indonesian region of Tana Toraja,

Keywords: photography, visual anthropology, Piotr Zbierski, Mircea Eliade, Carl Gustav Jung, interpretation of photography, visual sociology 